\title{
Az eurázsiai hód (Castor fiber LINNAEus, 1758) elterjedése és tevékenysége a Dél-Alföldön
}

\author{
JUHÁSZ ERIKA \\ Eötvös Loránd Tudományegyetem, Növényrendszertani, Ökológiai és \\ Elméleti Biológiai Tanszék, 1117 Budapest, Pázmány Péter sétány 1/C \\ E-mail: juhasz.erika43@gmail.com
}

\begin{abstract}
Összefoglalás: Az elmúlt évtizedekben az eurázsiai hód teljes európai elterjedési területén, így Magyarországon is sikeresen és gyorsan kolonizálta a számára alkalmas élőhelyeket. Az állománynövekedés nyomon követése és a hazai egyedszám meghatározása fontos feladat, de ehhez bizonyos térségekből, így a Dél-Alföldről eddig csak szórványos adatok álltak rendelkezésre. Az itt bemutatott, föként a Marosra és a Körösökre fókuszáló terepi felmérés (2016-2018), továbbá a helybéli lakosság bevonása, megkérdezése alapján készített áttekintés részben pótolja ezt a hiányosságot. A Maros 39,4 km hosszú vizsgált szakaszán 20, a Körösökön 99,7 km bejárása során 40 hódcsalád jelenlétére következtettem. A hód elsősorban a folyók hullámterében terjed a térségben, a mentett oldali csatornákon, holtágakon való előfordulása egyelöre kevésbé jellemző. A közleményben ismertetem a vizsgált területek fásszárú-kínálatáról és a fásszárú fajok hódok általi hasznosításáról gyüjtött adatokat is.
\end{abstract}

Kulcsszavak: állomány-monitoring, elterjedés, hódcsalád, Körös, Maros, Alsó-Tisza

\section{Bevezetés}

Az eurázsiai hód (Castor fiber) utódait fejlett módon gondozó, hosszú élettartamú, nagytestủ, kizárólag növényevő rágcsálófaj (STOCKER 1985, BOZSÉR 2001). Évente 1-3 (ritkán 4) kölyköt hoz a világra (STOCKER 1985, NOLET \& ROSSEL 1998), ennek ellenére a vadászatának sok évtizedes teljes tilalma, a sikeres hód-visszatelepítési programok és a spontán kolonizáció eredményeképpen a hódok egyedszáma Európa-szerte növekvő tendenciát mutat (HALLEY et al. 2012). Ezt a terjeszkedést a fásszárú vegetációval szegélyezett vizes élőhelyek jelentős kiterjedése, a hód rendkívüli alkalmazkodóképessége és a nagyragadozók hiánya teszi lehetővé. A hód territoriális állat (Rossel et al. 1998). A családon belüli egyedszámról átfogó felmérésen alapuló, kárpát-medencei adatok nem állnak rendelkezésre. Norvégiai területeken az átlagos csoportméretet 4,5 illetve 3,0 egyednek határozták meg, de az érték 1 és 11 között változott (CAMPBELL et al. 2005).

A hódterritórium jellemzően 1-2 km, maximum 5 km hosszúságú (VALACHOVIČ 2014, VOREL et al. 2016). A hosszúság függ a táplálékkínálattól és a populációdenzitástól (VALACHOVIČ 2014) valamint szezonális különbségeket is mutathat (VOREL et al. 2016), A hazai tapasztalatok szerint a rágással és egyéb életnyomokkal érintett, így a terepi felmérés során a territórium részeként azonosítható szakasz gyakran csupán 6-800 méter hosszú, de 
alacsony családsürüségnél jóval nagyobb is lehet (CZABÁN 2016). A rágások a territórium centrumában sürüsödnek, ez a centrumterület átlagosan 2-300 méter hosszú (CZABÁN 2017).

Az állomány növekedésével a fiatal egyedek új élőhelyek keresésére kényszerülnek, így eljutnak olyan víztestekre is, amelyek mentén emberi, gazdálkodói tevékenység jellemző. Rágásuk vagy építkezési szokásaik nyomán konfliktushelyzet alakulhat ki. Az együttélés feltételeinek megteremtése gyakran aktív beavatkozást igényel, ilyen például a helyi lakosság számára értéket képviselő fák egyedi védelme, faültetvények esetében a kerítésépítés, mezőgazdasági területeken a villanypásztor telepítése, hódgátak esetén az áteresz beépítése (VALACHOVIČ 2014, CAMPBELl-PALMER et al. 2015, VOREL et al. 2016). Vannak olyan területek, elsősorban alföldi folyók széles hullámterei, ahol a hódok tevékenysége gazdálkodói érdekekkel nem ütközik, vagy csak lokálisan és ritkán jelentkezik panasz. Ennek a kedvező állapotnak a fenntartása az egyedszám változásának nyomon követésével, a potenciális konfliktuspontok feltárásával, esetleg az érintett, helyi lakosságot célzó tájékoztatással, szemléletformással érhető el.

A WWF Magyarország visszatelepítési programjának keretei között Magyarországra hozott eurázsiai hódok több mint felét - 130 egyedet - a Tisza mentén és a környező vízfolyásokon, holtágakon engedték szabadon 2001 és 2008 között (HAARBERG 2007, BAJOMI 2011). A Közép-Tiszán a telepítéseket követően éves rendszerességgel történtek felmérések (TALLÓSI 2013). A hódok hamar eljutottak a Tisza mellékfolyóira is, a Zagyvára például 2006-ban (TALLÓSI 2007) A délkelet-magyarországi régióból, a Körösökröl, a Marosról és az Alsó-Tiszáról azonban mindeddig csak szórványos előfordulási adatok álltak rendelkezésre (CZABÁN 2016).

Célul tűztem ki, hogy átfogó képet alkossak az eurázsiai hód dél-alföldi elterjedéséről, megbecsüljem néhány kiválasztott Körös-szakaszon és a Maros teljes magyarországi szakaszán élö hódok állománynagyságát, továbbá feltárjam a térségben tapasztalható tevékenységüket, táplálkozási és építési szokásaikat.

\section{Anyag és módszer}

Részleges hód állományfelmérést végeztem a Körösök és a Maros mentén. A felmérés a következő szakaszokat érintette: a Fekete-Körös összefolyás feletti 15,8 km-e, a KettősKörös (90,5-99 fkm, továbbá a 103 fkm-től a Fekete- és Fehér-Körös összefolyásig tartó 24,9km), a Hármas-Körös 47-86 fkm, a Sebes-Körös körösladányi duzzasztó alatti 11,5 km-e, valamint a Maros 10,7-50,1fkm. A Körösök menti vizsgálatra a 2017 január végétől március közepéig terjedő időszakban, a Maros mentire 2018 márciusában került sor.

2016 márciusában területbejárást tettem az Alsó-Tiszán Algyő és a szerb határ között (159,6-189,1 fkm) és a Maros 0-4,5 fkm-én. Ezt a vizsgálatot egy tartós, magas vízszinttel jellemezhető időszak előzte meg, ami miatt a rágások a 177,2-189,1 fkm-en kevésbé koncentrálódtak a territóriumok központi részén, ezért a családszámot csak a 159,6-177,2fkmen becsültem. 2016 és 2018 között alkalomszerü megfigyeléseket végeztem a Dél-Alföld néhány kisebb csatornája mentén és a Mártélyi Tájvédelmi Körzetben is. 
A Maroson és az Alsó-Tiszán az adatgyüjtés motorcsónakból történt. A Körösökön az egyes szakaszok felmérése motorcsónakkal és/vagy gyalogos bejárással valósult meg, az alkalmazott módszert az Eredmények 1. és 2. táblázata ismerteti részletesebben. A motorcsónakos területbejárás hiánya egyedül a Fekete- és a Fehér-Körös összefolyásától a békési duzzasztóig terjedő szakaszon okozott problémát $(11,1 \mathrm{~km})$, ahol az iszapos partszegélyt nem lehetett mindenhol megközelíteni, ezért ott további hódcsaládok lehetnek jelen. A motorcsónakos felmérések minden esetben helyi természetvédelmi szakemberek vagy halörök segítségével zajlottak.

Az általam felmért és nem vizsgált Körös-szakaszokról egyaránt gyüjtöttem fotókkal bizonyított előfordulási adatokat 21 általam felkért adatközlőtől (13 szakirányú végzettségü természetvédő és kutató, négy halőr és négy, a témában jártas helyi lakos) és felhívásomra jelentkező horgászoktól, természetjáróktól, akiknek vízparti tevékenységük során számos lehetőségük kínálkozott a fajjal, valamint annak életnyomaival való találkozásra. Ezen adatgyüjtés során különös figyelmet fordítottam a Hármas-Körös 86-90,5fkm és a KettősKörös 99-103 fkm közötti szakaszára, valamint a Sebes-Körös alsó 2,5 km-re, melyek a 2017-es vizsgálatból kimaradtak, és összekapcsolják a felmért területeket.

A körösi és a mentett oldali gyalogosan bejárt területek esetében feljegyeztem a hódok számára rendelkezésre álló táplálékkínálat fásszárú fajösszetételét és a hód által megrágott fafajokat. Kis mértékü fogyasztásként definiáltam azt, amikor a rágás az adott fásszárú fajnak legfeljebb 5 darab, $15 \mathrm{~cm}$-es törzsátmérőnél vékonyabb egyedét érintette a feltételezett territóriumon belül. A territórium jellemzésekor kimagasló mértékủ rágási tevékenységnek neveztem azt, amikor a rágással érintett szakasz hossza meghaladta az 500 métert, a $15 \mathrm{~cm}$ nél vastagabb, befaragott törzsek száma pedig a 100 darabot.

Az állomány-monitoring módszertana a vegetációs perióduson kívül látható friss rágások (1/A-C ábra) egyszeri, GPS segítségével történő rögzítésén és a felvett pontok eloszlásának elemzésén alapul (CZABÁN 2017). A territórium határa felé közeledve az életnyomok ritkulnak, két territórium között általában egy több száz méter vagy néhány kilométer hoszszú szakasz következik, ahol nem, vagy csak elszórtan találhatóak rágások. Ez a szakasz a territóriumok számának növekedésével párhuzamosan egyre rövidebbé válik. A sürün benépesített élőhelyeken a más-más hódcsaládokhoz tartozó területek határát gyakran nehéz megállapítani. Kiegészitő információt jelentenek és a territóriumok központi részének pontosítását segítik a felmérés során megtalált várak (1/D ábra), az alacsony vízszintnél felszínre kerülő kotorékbejáratok (1/E ábra), a csapások, a vízbe vezető „csúszdák”, a lábnyomok (1/F ábra), a táplálékmaradványok és az élelemraktárak a kotorékszáj előtt. A téli időszakban a hódok által aktívan használt csapásokon a hódpézsma (castoreum) szagát érezhetjük (1/G ábra).

Az állomány nagyságát elsősorban a családok száma (territóriumok száma) értékkel lehet megbízhatóan jellemezni. Az Eredmények fejezet táblázataiban szereplő egyedszámértékeket (becsült minimális egyedszám) a korábbi hazai publikációkban és jelentésekben (BOZSÉR 2003, LELKES 2013, CZABÁN 2017) is használt módszerrel, a családok számát 3,5-tel szorozva kaptam meg. Mivel nem áll rendelkezésre felmérésen alapuló adat arról, hogy Magyarországon átlagosan hány egyedből áll egy-egy hódcsalád, ezért egy nagyobb szorzó alkalmazása a védett faj állományának túlbecsléséhez vezethet. Ugyanakkor más szerzők véleménye, lokális tapasztalata szerint Közép-Európában már érdemes lenne a 4-5 egyed/család értékkel számolni (ČANÁDY et al. 2016). 


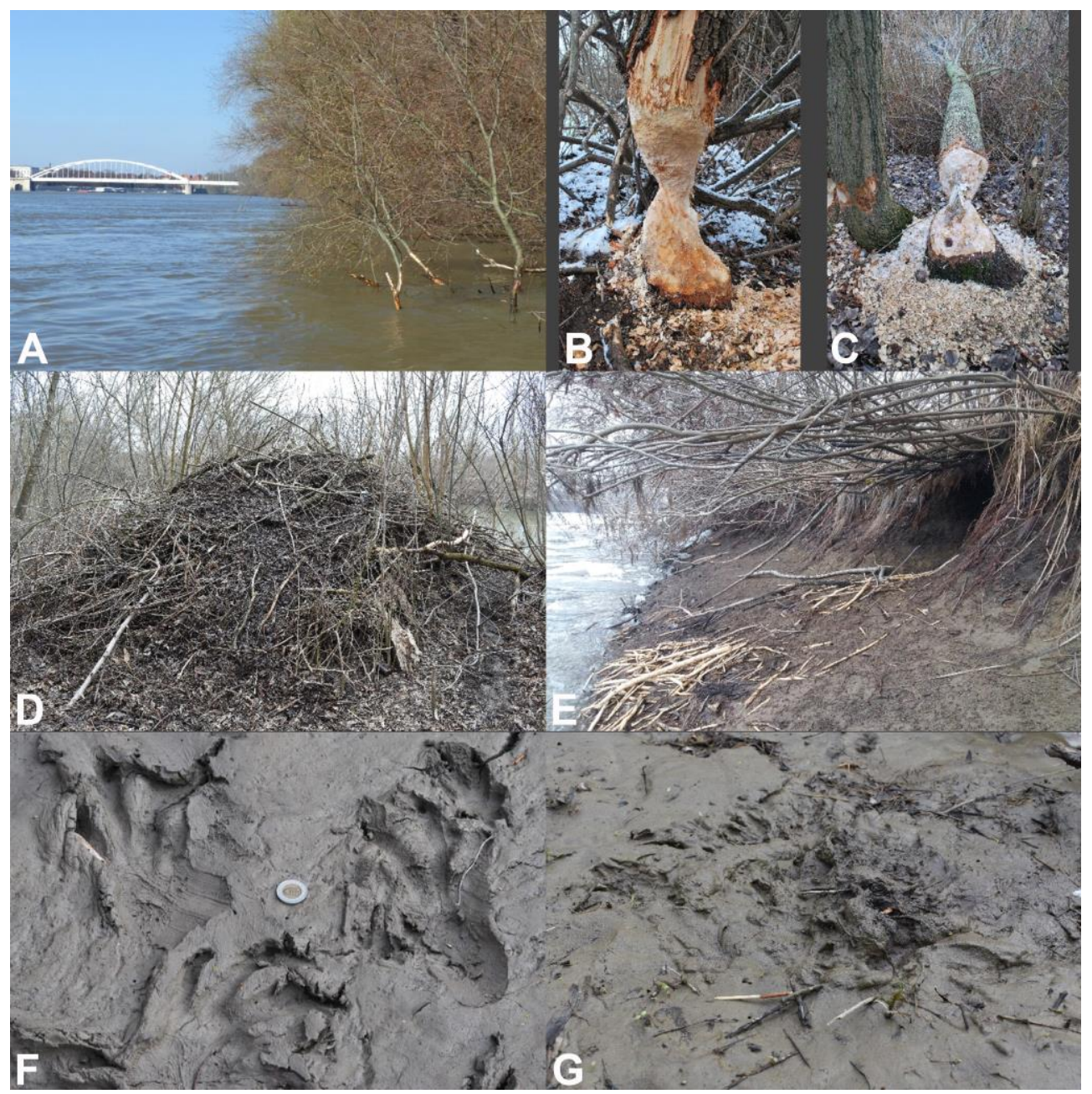

1. ábra. Hód életnyomok. A: rágott ágak a Tiszán, Szeged belterületén (fotó: TANÁcs EsZTER);

B-C: látványos fadöntések; D: hódvár a Sebes-Körösön; E: alacsony vízszintnél felszínre került üreg; F: lábnyomok; G: területjelölés castoreummal.

Figure 1. Signs of beaver activity. A: chewed branches on the Tisza River in Szeged (photo: ESZTER TANÁCS); B-C: felling of trees - spectacular examples D: beaver lodge on the Sebes-Körös River; E: burrow at low water level; F: footprints; G: scent mark with castoreum. 


\section{Eredmények}

\section{Elterjedés}

A 2017-ben gyüjtött adatok a Fekete-Körösön négy család jelenlétét bizonyították. A friss rágások mellett régieket is feljegyeztem, tehát a hódok legalább 1-2 éve lakják ezt a folyószakaszt. A jobb parton, a román határ közelében talált lekérgezett ágak, táplálkozóhelyek további példányok előfordulására engednek következtetni. 2018-ban az adatközlök a Fekete- és Fehér-Körös romániai szakaszán, valamint a két Körös összefolyása felett, a Fehér-Körösön is észleltek rágásokat.

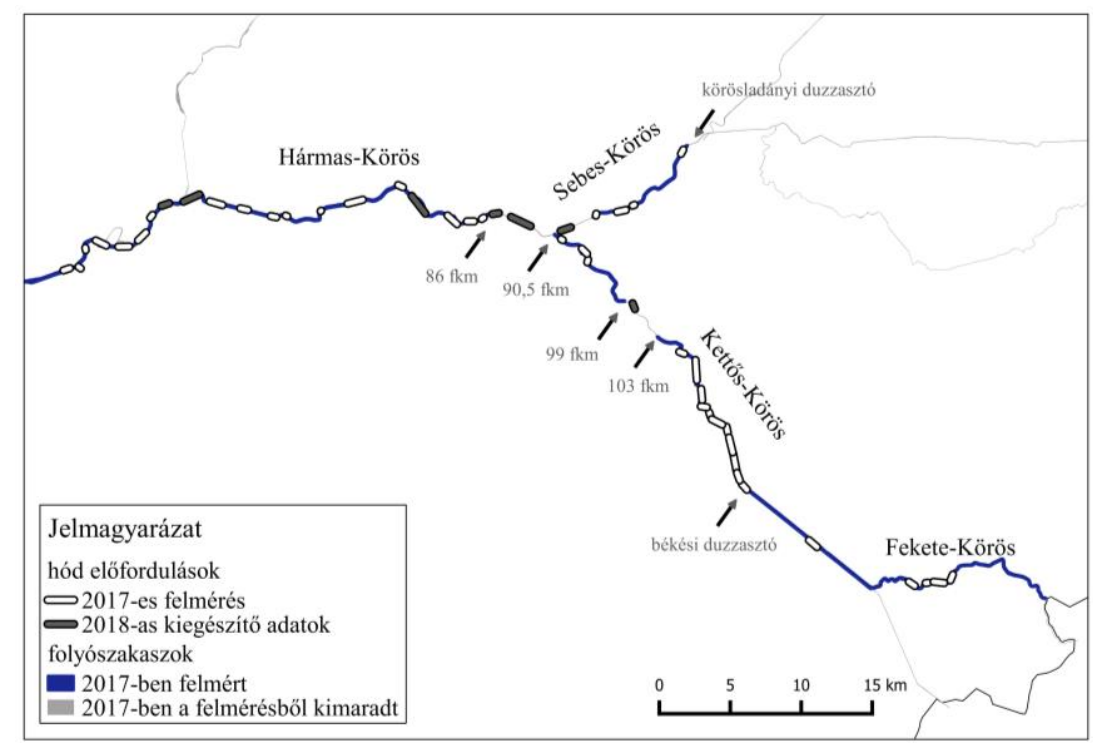

2. ábra Hód elöfordulások a Fekete-Körösön, a Kettős-Körösön, a Hármas-Körös felső szakaszán (47-90,5 fkm) és a Sebes-Körös alsó szakaszán a 2017-es felmérés, az adatközlők 2018-as, fotókkal dokumentált észlelései és HARSÁNYi DEZső adatai alapján.

Figure 2. Beaver sites along the Fekete-Körös River (Crișul Negru), Kettös-Körös River, in the upper section of the Hármas-Körös River and in the lower section of the Sebes-Körös River (Crișul Repede) The map was constructed using the field survey data (2017) and the additional data collected in 2018 by DEZSÖ HARSÁNYI and other informants. 
1. táblázat A hódcsaládok becsült száma a Körös-vidék vizsgált területein. A családsűrüséget kizárólag az általam megtalált életnyomok és a bejárt szakaszok hosszúsága alapján számítottam.

Felmérő/adatközlő személyek: BZ = BOGDÁNY ZOLTÁN, HD = HARSÁNYI DEZSÖ, HDP = HOLÓKA DEMETER PÉTER, JE = JUHÁSZ ERIKA, JZS = JANKULÁR ZSOLT, SL = SEBESTYÉN LÁSZLÓ.

Felmérés módja: $\mathrm{p}=$ partról végzett, gyalogos bejárás, $\mathrm{m}=$ motorcsónakos bejárás, $\mathrm{a}=$ alkalomszerü adatgyüjtés, $r=$ részleges felmérés, hiányos adatok, $n$. a. = nincs adat.

Table 1. Estimated number of beaver colonies in the examined areas of the Körös region. Surveyors and informants: BZ = ZOLTÁN BOGDÁNY, HD = DEZSÖ HARSÁNYI, HDP = DEMETER PÉTER HOLÓKA, JE = ERIKA JUHÁSZ, JZS = ZSOLT JANKULÁR, SL = LÁSZLÓ SEBESTYÉNN

Columns: 1. - area, 2. - number of colonies, 3. - number of individuals, 4. - density of colonies (number of colonies $/ 10 \mathrm{~km}$ ), 5. - surveyor/informant, 6. - comments.

Method of the survey (integrated in column 5): $\mathrm{p}=$ survey made by walking along the riverbank, $\mathrm{m}=$ motorboat, $\mathrm{a}=$ occasional data collection, $\mathrm{r}=$ partial survey, incomplete data, $\mathrm{n} . \mathrm{a} .=$ no data.

\begin{tabular}{|c|c|c|c|c|c|}
\hline terület & $\begin{array}{l}\text { család- } \\
\text { szám }\end{array}$ & $\begin{array}{l}\text { becsült } \\
\text { egyedszám }\end{array}$ & $\begin{array}{l}\text { családsürüség } \\
\text { (család/10 km) }\end{array}$ & $\begin{array}{l}\text { felmérő } \\
\text { (felmérés módja) }\end{array}$ & megjegyzés \\
\hline $\begin{array}{l}\text { Fekete-Körös } \\
\text { (15,8 km) }\end{array}$ & 4 & 14 & 2,53 & $\mathrm{JE}(\mathrm{p})$ & három vár \\
\hline $\begin{array}{l}\text { Kettős-Körös a } \\
\text { békési } \\
\text { duzzasz-tóig } \\
(11,1 \mathrm{~km})\end{array}$ & $\min .1$ & 4 & - & $\mathrm{JE}(\mathrm{p}, \mathrm{r})$ & $\begin{array}{l}\text { szórványos } \\
\text { rágások }\end{array}$ \\
\hline $\begin{array}{l}\text { Kettős-Körös: a } \\
\text { békési } \\
\text { duzzasz-tótól } \\
\text { a } 103 \text { fkm-ig } \\
\text { (13,8 km) }\end{array}$ & 11 & 39 & 7,97 & $\mathrm{JE}(\mathrm{p}, \mathrm{m})$ & - \\
\hline $\begin{array}{l}\text { Kettős-Körös } \\
\text { 90,5-99 fkm }\end{array}$ & 3 & 11 & 3,53 & $\mathrm{JE}(\mathrm{p})$ & - \\
\hline $\begin{array}{l}\text { Sebes-Körös } \\
\text { felmért sza- } \\
\text { kasz }(11,5 \\
\text { km) }\end{array}$ & 4 & 14 & 3,478 & $\mathrm{JE}(\mathrm{p})$ & - \\
\hline $\begin{array}{l}\text { Hármas-Körös } \\
\text { 47-86 fkm }\end{array}$ & $\begin{array}{l}17 \\
(2017)\end{array}$ & $\begin{array}{l}60 \\
(2017)\end{array}$ & $\begin{array}{l}4,36 \\
(2017)\end{array}$ & $\begin{array}{l}\text { JE, BZ, JZS } 2017 \\
(\mathrm{~m}, \mathrm{p}) \text { HD } 2018(\mathrm{~m})\end{array}$ & - \\
\hline $\begin{array}{l}\text { Hármas-Körös } \\
\text { 0-47 fkm }\end{array}$ & n. a. & n. a. & - & n. a. & - \\
\hline $\begin{array}{l}\text { Körös hullám- } \\
\text { téri holtágak }\end{array}$ & $\begin{array}{l}3 \text { hely- } \\
\text { szín }\end{array}$ & - & - & BZ, JZS, HD (a) & $\begin{array}{l}\text { Gyigerzugi-, } \\
\text { Aranyosi- } \\
\text { holtág, } \\
\text { Kákafoki- } \\
\text { holtág befolyó }\end{array}$ \\
\hline $\begin{array}{l}\text { Hármas-Körös } \\
\text { mentett oldali } \\
\text { holtágak }\end{array}$ & 0 & 0 & - & - & - \\
\hline $\begin{array}{l}\text { Sebes-Körös } \\
\text { mentett oldal }\end{array}$ & 1 & 1 & - & HDP (a) & Dió-ér \\
\hline
\end{tabular}


A Kettős-Körösön, a Fekete- és a Fehér-Körös összefolyásától a békési duzzasztóig $(11,1 \mathrm{~km})$ csak egy család életnyomait regisztráltam gyalogos bejárás során, de a partszegélyt nem tudtam mindenhol megközelíteni.

A békési duzzasztótól a $103 \mathrm{fkm}$-ig terjedő szakaszon $(13,8 \mathrm{~km})$ tapasztaltam a legmagasabb családsürüséget (1. táblázat). Köröstarcsa közelében egy $5 \mathrm{~km}$ hosszú szakaszon (94-99fkm) egyáltalán nem észleltem hódaktivitást (2. ábra). Eredményeim alapján a Kettős-Körösön 2017-ben a családok száma összesen 15 volt. A 99. és 103 . fkm között az adatközlők 2017-ben még nem, 2018-ban viszont egy területen rendszeresen figyelték meg a hódokat és azok életnyomait.

A Sebes-Körös körösladányi duzzasztó alatti szakaszán talált életnyomok négy család jelenlétére utaltak. A torkolat előtti 2,5 km hosszú, általam be nem járt szakaszon egy adatközlő egy ötödik család meglétét igazolta. Az adatközlők a Sebes-Körösön már 2007-ben is dokumentálták a hódokkal való találkozásukat. (Az első hármas-körösi észlelés csak 2010ben történt.)

A Berettyó-torkolat környékéröl, a Sebes-Körös Körösladány fölötti szakaszáról (Újiráz, Körösújfalu), valamint a mentett oldalról (Dió-ér) is jelezték a faj tevékenységét. A 47-es út Körösladány és Szeghalom közötti szakaszáról pedig egy elütésről kaptam információt. A hód már évekkel ezelött megjelent a romániai Berettyó-szakaszon is (FÜLÖP TIHAMÉR szem. közl.). A Hortobágy-Berettyóról nem érkezett hódokkal kapcsolatos adat, az adatközlök egyike célzott, motorcsónakos kereséssel sem találkozott hódra utaló nyomokkal a folyó alsó $40 \mathrm{~km}$-én.

A Hármas-Körösön bejárt 39 km-en (47-86 fkm) 17 családot regisztráltunk. 2018-ban HARSÁNYI DEZSŐ adatai alapján arra következtettem, hogy itt a tavaszi árvíz ellenére valamennyi család megmaradt, és további 3 új jelent meg, a 2017-ben nem vizsgált 4,5 km-en (86-90,5 fkm) pedig 2 család volt jelen, tehát ez összesen 22 család.

A Körösök 2017-ben felmért szakaszain (együttesen 99,7 km) összesen 40 család életnyomait sikerült azonosítani. A kimaradt szakaszokról (Hármas-Körös 86-90,5fkm, Kettős-Körös 99-103 fkm és Sebes-Körös alsó 2,5 km) érkezett adatok alapján a folyó egybefüggő 110,7 km-én minimum 46 hódcsalád élhet.

Az adatközlők a Hármas-Körös 0-47 fkm közötti szakaszáról több helyről is küldtek egymástól független megfigyeléseket, információik szerint a hód a folyón végig jelen van. Olykor holtágak közelében is tapasztalható az aktivitás erősödése, ugyanakkor a jelzett észlelések alapján a faj holtágakon való tartós megtelepedésére még a hullámtéren (az ártér árvízvédelmi töltések által közrefogott területén) belül is kevés a példa (Gyigerzugi-holtág, Aranyosi-holtág, Kákafoki-holtág befolyó). A hódot a mentett oldali (hullámtéren kívüli) holtágak egyikéről sem jelezték.

A Maros 10,7 és 50,1 fkm között végzett felmérés során 20 családot regisztráltunk (3. ábra), ez alapján 26 családra becsültem a folyó teljes hazai szakaszán $(50 \mathrm{~km})$ élő hódok állományát. 


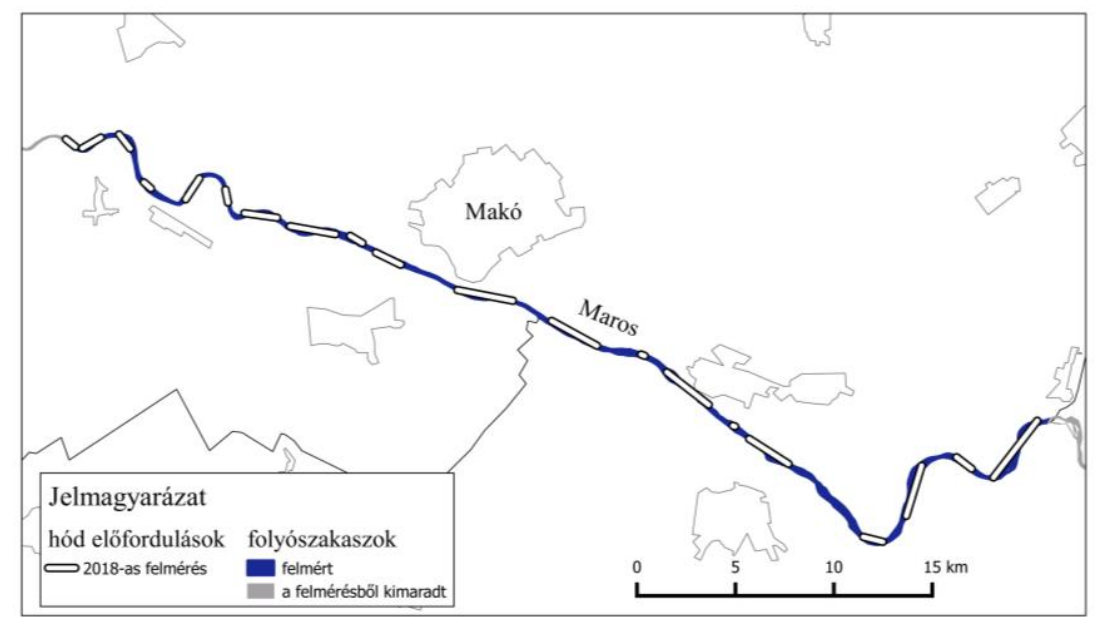

3. ábra. Hód előfordulások a Maros mentén (10,7-50,1fkm) a 2018-as felmérés alapján.

Figure 3. Beaver sites along the Maros (Mureș) River (10.7-50.1 fkm) based on the field survey in 2018.

2016-ban az Alsó-Tisza 159,6-189,1 fkm bejárása során Szegeden a Maros torkolatától (177,2 fkm) a Boszorkányszigetig (172 fkm) három, a Boszorkányszigettől a szerb határig (159,6 fkm) további négy családot jegyeztem fel (2. táblázat). 189,1-177,2fkm között nem becsültem családszámot, azonban a rágások teljes hiánya maximum $700 \mathrm{~m}$ hosszú szakaszokon fordult elő. 2017-ben egy negyedik család is létezett Szegeden, de az a jelentős csónakforgalom okozta zavarás következtében hamar eltűnt a területről. 2018-ban helyi horgászok a Tisza Csongrád és Szeged közötti szakaszáról számos további adatot küldtek.

Az Alsó-Tiszán 4 elhullásról szereztem tudomást, két tetem esetében a pusztulás oka nem tisztázódott, a másik kettő a folyóvízi halászat betiltása előtti időszakban varsába fulladt kölyök volt.

Az Alsó-Tisza mentén, Mindszenttől délre lévő holtágakon jelentős hódaktivitás nem tapasztalható. A Mártélyi-holtágon néhány rágás az utóbbi években is előkerült, tehát él hód a területen. A Körtvélyesi-holtág kifolyójánál (Tűfarok) 2016 nyarán a helyi természetvédelmi szakemberekkel frissen lemetszett ágakat találtunk. Az ezt követő adatok 2018 tavaszáról származnak: a holtágon és a belső területeken szórványos rágások jelentkeztek. A természetvédelmi őrszolgálat tagjai által a Sasérnél és az Atkai-holtágon végzett alkalmi területbejárások során a faj előfordulására utaló jel nem került elö. 
2. táblázat. A hódcsaládok becsült száma a Maroson és a Tisza menti vizsgált területeken. A családsürüséget kizárólag az általam megtalált életnyomok és a bejárt szakaszok hosszúsága alapján számítottam. Felmérő/adatközlő személyek: AA = ALBERT ANDRÁs, BD = BÁLINT DÉNES, BI = BÁRTOL ISTVÁN, JE = JUHÁSZ ERIKA, LP = LOVÁSZI PÉTER, PJ = PUSKÁS JÓZSEF.

Felmérés módja: $\mathrm{p}=$ partról végzett, gyalogos bejárás, $\mathrm{m}=$ motorcsónakos bejárás, $\mathrm{a}=$ alkalomszerü adatgyüjtés, $r=$ részleges felmérés, hiányos adatok.

Table 2. Estimated number of beaver colonies along the Maros River, Tisza River and smaller water bodies. Surveyors and informants: AA = ANDRÁS AlBERT, BD = DÉNES BÁLINT, BI = ISTVÁN BÁRTOL, JE = ERIKA JUHÁSZ, LP = PÉTER LOVÁSZI, PJ = JÓZSEF.PUSKÁS.

Columns: 1. - area, 2. - number of colonies, 3. - number of individuals, 4. - density of colonies (number of colonies $/ 10 \mathrm{~km}$ ), 5. - surveyor/informant, 6. - comments.

Method of the survey (integrated in column 5): $\mathrm{p}=$ survey made by walking along the riverbank, $\mathrm{m}=$ motorboat, $\mathrm{a}=$ occasional data collection, $\mathrm{r}=$ partial survey, incomplete data.

\begin{tabular}{|c|c|c|c|c|c|}
\hline terület & $\begin{array}{l}\text { család- } \\
\text { szám }\end{array}$ & $\begin{array}{l}\text { becsült } \\
\text { egyedszám }\end{array}$ & $\begin{array}{l}\text { családsürüség } \\
\text { (család/10 km) }\end{array}$ & $\begin{array}{l}\text { felmérō } \\
\text { (felmérés módja) }\end{array}$ & megjegyzés \\
\hline $\begin{array}{l}\text { Maros } \\
10,7-50,1 \mathrm{fkm}\end{array}$ & 20 & 70 & 5,08 & JE, LP (m) & - \\
\hline $\begin{array}{l}\text { Alsó-Tisza } \\
159,6-177,2 \\
\text { fkm }\end{array}$ & 7 & 25 & 3,98 & JE, AA (m) & - \\
\hline Mártélyi-holtág & 1 & - & - & $\mathrm{AA}, \mathrm{BD}, \mathrm{JE}(\mathrm{a}, \mathrm{r})$ & $\begin{array}{l}\text { friss és régi } \\
\text { szórványos } \\
\text { rágások }\end{array}$ \\
\hline $\begin{array}{l}\text { Körtvélyesi- } \\
\text { holtág }\end{array}$ & 1 & - & - & $\mathrm{AA}, \mathrm{BD}(\mathrm{a}, \mathrm{r})$ & $\begin{array}{l}\text { szórványos } \\
\text { rágások }\end{array}$ \\
\hline $\begin{array}{l}\text { Sasér és Atkai- } \\
\text { holtág }\end{array}$ & 0 & 0 & - & PJ (a) & - \\
\hline $\begin{array}{l}\text { Alsó-Tisza } \\
\text { mentett oldali } \\
\text { ártér, csatornák }\end{array}$ & 4 & 15 & - & PJ, JE (p) & $\begin{array}{l}\text { Kenyere-ér, } \\
\text { Kósd- } \\
\text { Porgányi szo- } \\
\text { rítógátas csa- } \\
\text { torna, Puszta- } \\
\text { szeri TK } 2 \\
\text { helyszín }\end{array}$ \\
\hline $\begin{array}{l}\text { Tiszaalpár- } \\
\text { bokrosi ártéri } \\
\text { öblözet }\end{array}$ & $10-12$ & 39 & - & BI (a) & - \\
\hline
\end{tabular}

A Tiszaalpár-bokrosi ártéri öblözetben jelenleg 10-12 hódcsalád él (BÁRTOL ISTVÁN szem. közl.).

A Hódmezővásárhely külterületén található Kenyere-eret a hódok 2006 óta folyamatosan lakják (SOMODI ISTVÁN szem. közl.). A Kósd-Porgányi szorítógátas csatornán is megjelent a faj. A Duna-Tisza közén, a Tisza hullámterén kívül a hód elöfordulása egyedül a Pusztaszeri Tájvédelmi Körzetben ismert, ahol a vizsgálati időszakban két család élt. 


\section{Megfigyelések a kotorékhely és a táplálkozóhely kiválasztásával kapcsolatban}

A Fekete-Körösön a hódcsaládok által kolonizált területek mindegyike szélesebb, fás növényzettel kísért szakaszon, sürü cserjeszint védelmében helyezkedett el. A KettősKörösön ugyanez nem volt megfigyelhető. Idősebb, egy sorból álló part menti fás vegetáció esetében is jegyeztem fel fakidöntést, rágást, míg a kiterjedtebb füzligetekben nem minden esetben. A füzligetek egy részében az üregásásra alkalmas szakaszok hiányoztak. Kotorékbejáratokat és várakat csak meredek partokon, olykor szakadópartokon találtam. A rágások legtöbbször szórványosan jelentkeztek, szakadópartok (közel függőleges partfalak) esetében néhány, a víz felöl könnyebben megközelíthető foltra koncentrálódtak. A szakadópartokat a hódok abban az esetben kerülték el, amikor annak hosszúsága és magassága szinte lehetetlenné tette a parton álló fásszárú táplálékkínálat megközelítését. A Maros szigetei fontos táplálkozóhelyet jelentettek a hódok számára, a folyó valamennyi szigetén találtam rágásokat.

\section{Táplálkozás}

A Fekete-Körösön a lombkoronaszintben a füz (Salix spp.), a cserjeszintben a gyalogakác (Amorpha fruticosa) uralkodott. A hódok kis mennyiségben ugyan, de az utóbbit is fogyasztották. A rágások száma csekély, az itt élő egyedek tevékenysége nem feltünő.

A Kettős-, a Sebes- és a Hármas-Körösön a füz- és nyárfajok (Salix spp., Populus spp.) mellett jelentős az inváziós fafajok, a gyalogakác, az amerikai kőris (Fraxinus pennsylvanica) és a zöld juhar (Acer negundo) térnyerése. Az őshonos puhafák esetében a letört ágak hód általi fogyasztását és a vastagabb törzsek megkezdését is sok helyen tapasztaltam. Az inváziósok rágása, kidöntése nem volt jellemző minden territóriumban, és egy eset kivételével csak a $20 \mathrm{~cm}$-nél vékonyabb törzseket érintette. Ugyanakkor egy sebeskörösi területen 2017 és 2018 között a hód szinte kizárólag amerikai kőrist és zöld juhart döntött ki (sűrün növő, karvastagságú egyedeket), melyeket várépítésre is felhasznált. Kimagasló mértékü rágási tevékenységet a Körösök mentén három helyen figyeltem meg (egy-egy territóriumban a Kettős-, a Sebes- és a Hármas-Körös mentén). Ezen helyszínek egyikén (Hármas-Körös) sürü gyalogakácos sáv kíséri a vízpartot, melyböl 8-25 cm vastag szürke nyarak (Populus x canescens) emelkednek ki. A hód föként az utóbbiakat döntötte (4. ábra). Az inváziós cserje jelentős kínálati aránya ellenére kevesebb, mint negyven 1-3 cm vastag gyalogakácágat metszett le ezen a több mint $1 \mathrm{~km}$ hosszú szakaszon. 


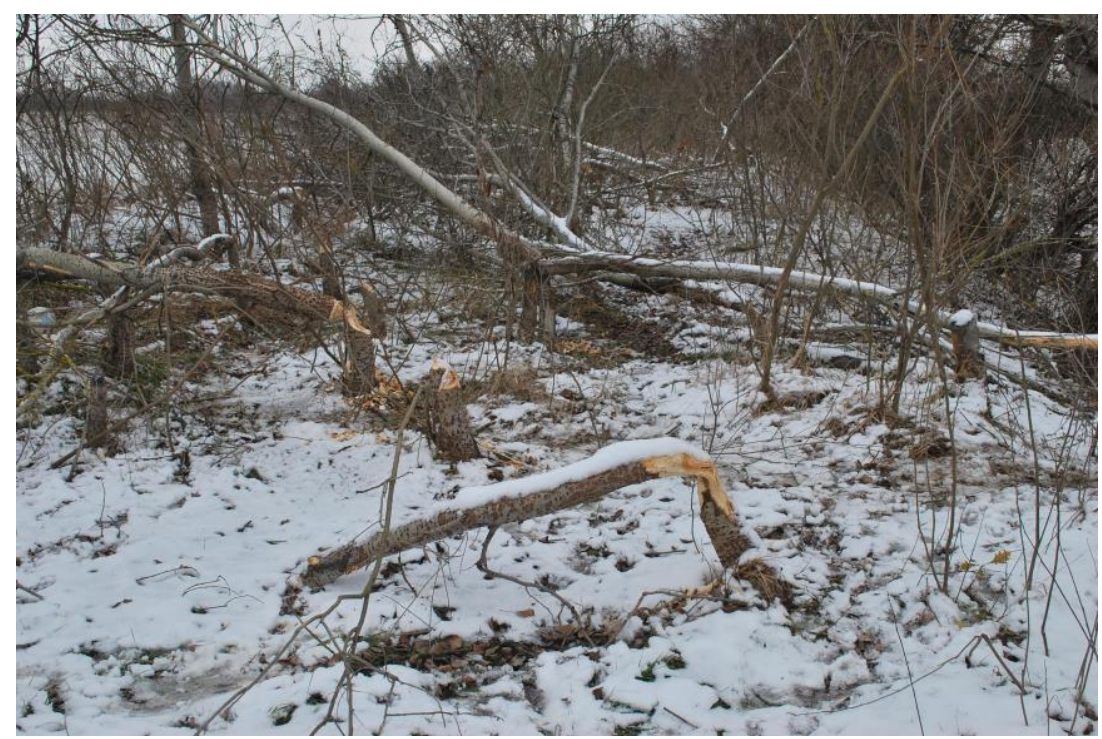

4. ábra. Sürü gyalogakácosban kidöntött szürke nyár törzsek.

Figure 4. Beaver selected young Populus $x$ canescens trunks in a dense Amorpha fruticosa shrubbery.

Nemesnyár kidöntését a Körös-vidéken két esetben regisztráltam, mindkét alkalommal fiatal ültetvényben (egy-egy területen a Kettős- és a Sebes-Körös mentén.) A KettősKörösnél a rágás több sor csemetét érintett. A hód 30-45 méterre is eltávolodott víztől a vékony nemesnyártörzsek megszerzése érdekében.

A Maroson a hód tevékenysége a fiatal füzesek legtöbbjében megfigyelhető volt (különösen a szigetcsúcsokon). Az Alsó-Tiszán az elsődleges fásszárú táplálékforrást a vizsgálat éveiben a víz fölé lógó vagy szél által letört füz- és nyárfaágak jelentették.

A Tiszaalpár-bokrosi ártéri öblözetben is létezett egy olyan territórium, ahol egy gyalogakáccal erösen fertőzött területen a frissen rágott füztörzsek száma meghaladta a százat. Ugyanitt 2018-ban lemetszett gyalogakác ágat nem találtam.

A dél-alföldi csatornák mentén a táplálékkínálat jóval változatosabb. A Kenyere-érnél a hód több évben is nagy mennyiségben hordta be a vízbe a kukoricát (Zea mays) a szomszédos földekről, 10-50 méter távolságból (5. ábra). A fásszárúak közül a szürke nyarat, a fehér füzet (Salix alba), a cseresznyeszilvát (Prunus cerasifera), az amerikai kőrist és a mezei szilt (Ulmus minor) fogyasztotta. A Kósd-Porgányi szorítógátas csatornán a kínálatban nem szerepeltek füz fajok, a fiatal nyarak mellett a hód gyümölcsfákat, házi almát (Malus domestica) és nemes szilvát (Prunus domestica) is megrágott. A kökény (Prunus spinosa) és cseresznyeszilva fogyasztása kismértékünek bizonyult. 


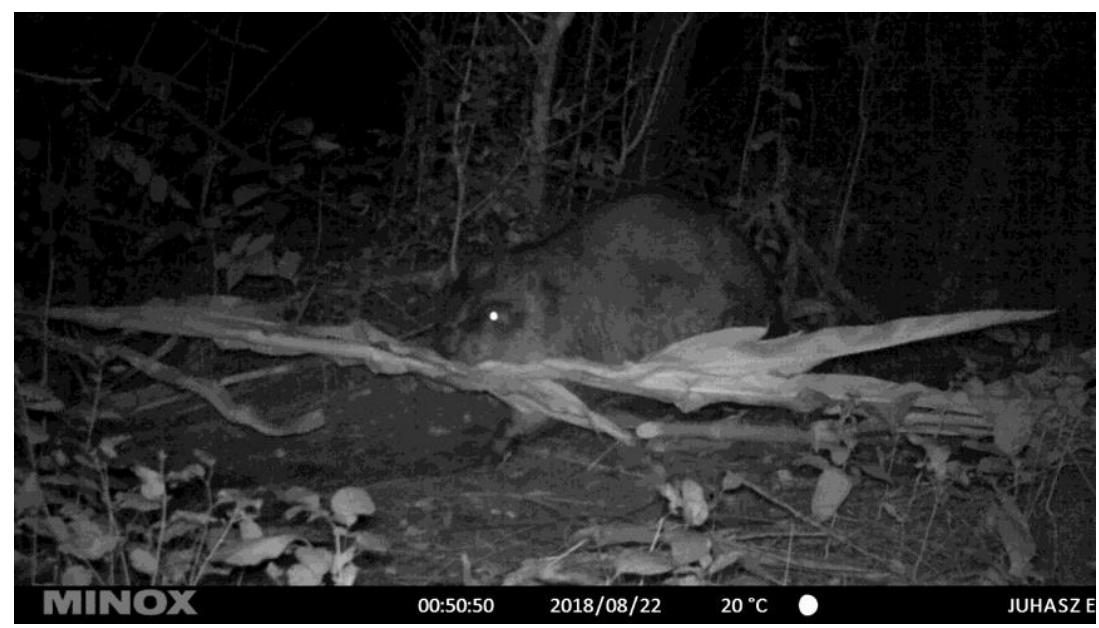

5. ábra. Hód kukoricaszárat húz a kotorék felé Hódmezővásárhely közelében.

Figure 5. A beaver pulls a leafy stalk of maize in the direction of the burrow near Hódmezővásárhely.

A Pusztaszeri Tájvédelmi Körzetben az egyik helyszínen csupán a fehér füz és a szürke nyár jelenti a kínálatot (mindkettőt fogyasztotta). A másik helyszínen a nemesnyár és a fehér akác (Robinia pseudoacacia) dominál. Előbbit a hód jelentős mennyiségben döntötte ki, de az erdőgazdálkodó ezzel kapcsolatban kárt a nemzeti park felé nem jelzett (PUSKÁs JóZSEF szem. közl.). Fadöntést, rágást tapasztaltam még ebben a territóriumban a következö fajoknál: amerikai kőris, fehér eper (Morus alba), cseresznyeszilva, fehér füz, spirálfüz (Salix matsudana 'Tortuosa'), fehér akác (egyetlen törzs).

A gyalogakác, az egybibés galagonya (Crataegus monogyna), az ezüstfa (Elaeagnus angustifolia), a rózsa (Rosa spp.) és a fekete bodza (Sambucus nigra) három csatorna partján is nagy mennyiségben volt jelen, de ezek közül csak a fekete bodzán találtam metszést (kis mértékü fogyasztás egy területen).

\section{Építés}

A vizsgálat idején hódgátat egyik területen sem találtam, ez a típusú építkezés a gyüjtött információk alapján ma még egyáltalán nem fordul elő a Dél-Alföldön. A Kenyere-érnél élő hódcsalád a vízszintet úgy próbálta stabilizálni, hogy a szabályozó zsilipet kukoricaszárral, -levéllel és iszappal tapasztotta. A faj a térségben jellemzően kotorékokat használ, a várépítés nem általános jelenség. Gyalogos bejárásaim során 13 territórium esetében jegyeztem fel várat (Fekete-Körös 3, Kettős-Körös 2, Sebes-Körös 2, Hármas-Körös 2, Pusztaszeri Tájvédelmi Körzet 1, Tiszaalpár-bokrosi ártéri öblözet 3). A Körös-vidék legnagyobb ismert hódvára a Sebes-Körösön található, átmérője meghaladja az 5 métert, magassága pedig a másfél métert. A Tiszaalpár-bokrosi ártéri öblözetben az egyik territóriumban a hódok magas vízszint esetén egy 1,5-2 méter magas, ágakból épített búvóhelyet, „árvízi várat” használnak átmeneti menedékként. 


\section{Értékelés}

A Körösök 110,7 km hosszú egybefüggő szakaszán a családok becsült száma a vizsgálati időszakban 46 volt. A Fekete-, a Sebes- és a Hármas-Körös további, nem vizsgált szakaszain (összesen $97 \mathrm{~km}$ ) a Körösökön tapasztalt legkisebb családsürüséggel (2,53 család/10 km) számolva 24, az átlagos értékkel (4,17 család/10 km) számolva 40 család lehetett jelen. Valószínüsíthető, hogy a hódok Körösökön való elterjedésének folyamata a Hármas-Körösön kezdődött, az egyedek a közép- és alsó-tiszai visszatelepítési helyszínek felöl érkezhettek.

Becslésem szerint 2018-ban a Maroson minimum 26 család volt jelen. Nem állítható, hogy az ottani hódcsaládok kizárólag a tiszai helyszíneken elengedett egyedektől származhatnak, mivel Romániában is történt visszatelepítés a Maros mentén (IONESCU et al. é.n.). Az Alsó-Tiszán a felmérési eredmények és a helyiektől kapott információk érzékeltetik, hogy a faj az egész folyón elterjedt. A hódok mentett oldali csatornákon, holtágakon való előfordulása egyelőre kevésbé jellemző.

A Dél-Alföldet kolonizáló hódok élőhelyválasztását tanulságos lett volna a kezdetektől nyomon követni. Az élőhelyalkalmasság kérdésköre Európában elősorban a visszatelepítések idején kapott jelentős figyelmet. A felmérések során a part meredekségét, magasságát, anyagát, a víz mélységét, szélességét, sodrását, valamint a lágy- és fásszárú növényzet borítását is figyelembe kell venni (MACDONALD et al. 2000). A Körösök mentén a hód a böséges, föként puhafafajokból álló kínálat ellenére egyelöre elkerüli azokat a lapos partokat, amelyeken a partszegélyen sok száz méteren vagy több kilométeren keresztül nem található kotorékásásra alkalmas kiszögellés. A $45^{\circ}$-ot meghaladó meredekségű szakasz meglétét az alsó- és közép-tiszai WWF visszatelepítéseket megelőző területbejárások során is alapkritériumnak tekintették, de a szakadópartokat alkalmatlannak tartották (BOzSÉR 2002, HAARBERG-BOZSÉR 2005). A körösi tapasztalatok azt mutatják, hogy ma már nem csak változatos partjelleg mellett, hanem hosszú szakadópartokon is megfigyelhetünk rágásokat olyan esetekben, amikor azoknak van néhány kisebb lejtésű pontja, ahol a hód felkapaszkodva eléri a számára kedvező táplálékforrást. A lokális élőhelyalkalmassági felmérések során döntő fontosságúnak tartották a stabil vízszintet, mivel az áradásokkor a hód elhagyja a kotorékát, és úgy vélték, hogy ez a telepítés sikerét (az állatok életben maradását) veszélyeztetheti (HAARBERG-BOZSÉR 2005). Ennek kockázata természetesen nem zárható ki, de a 2017-es saját és a 2018-ban kapott, árvíz utáni hármas-körösi adatok összevetése nem mutatott rá ilyen hatásra, a családok megmaradtak, sőt egy év alatt újabbak is megjelentek. A Körösök mentén a hód egyelőre keresi a zavartalanabb, emberi tevékenységgel nem érintett helyeket, ám az Alsó-Tiszán már városi környezetben, a Tisza szegedi, belvárosi szakaszán is megjelenik.

A Mártélyi- és Körtvélyesi-holtág, valamint a Sasér a WWF visszatelepítési helyszínei voltak, de a területeken ma is csekély a hódok aktivitása. A Körtvélyesi-holtággal és a Saséri helyszínnel a korábbi élőhelyalkalmassági felmérés is foglalkozott, mely előbbit megfelelőnek találta a hódok tartós megtelepedésére, utóbbit azonban nem (HAARBERGBOZSÉR 2005). Ugyanakkor a fokozottan védett Sasér - ha tartós élőhelyet nem is - biztonságos környezetet jelenthetett az akkor még ritka faj példányainak elengedésére. A Körtvélyesi-holtágat a hódok a kiengedés után néhány napon belül elhagyták és a Kenyereérre költöztek át. A Saséren, az Atkai-holtágon és a környező kisebb csatornákon a Tisza 
jobb parti töltésén kívül a telepítést követö években nem találtak rágásokat (SOMODI ISTVÁN szem. közl.). A hódok által sikeresen kolonizált Tiszaalpár-bokrosi ártéri öblözetet azonban az élőhelyalkalmassági felmérés a jelentések szerint nem érintette (BOzsÉR 2002, HAARBERG-BOzSÉR 2005). A telepítési helyszínek kiválasztását nehezítette, hogy a más országokban készített élőhelyalkalmassági modellek (ALLEN 1983, MACDONALD et al. 2000) nehezen adaptálhatók, és hazai modellek nem állnak rendelkezésre (HAARBERG 2007). Egész Európában jól prediktáló, egyszerü preferenciamodell vagy alkalmassági index megalkotása nem lehetséges (HARTMAN 1996).

A hód a vizsgált Körös-, Maros- és Tisza-szakaszokon a territóriumok többségében az őshonos puhafákat fogyasztotta legnagyobb mennyiségben. Gemencen szintén a füz és nyár fajok: a csigolyafüz (Salix purpurea), a mandulalevelü füz (Salix triandra), a fehér füz és a fehér nyár (Populus alba) rágása a legjellemzőbb (BozsÉr 2001). A puhafákból rendelkezésre álló kínálat kiemelten fontos a hódok számára, az élőhelyválasztásukat is meghatározza (FUSTEC et al. 2001, JOHN \& KOSTKAN 2009).

Egy hármas-körösi és egy tiszaalpári gyalogakáccal erősen fertőzött területen tapasztaltam azt, hogy a puhafák fogyasztása kis lokalitásokon belül jelentős hatást gyakorolhat az őshonos és az inváziós fajok versenyhelyzetére. A témakör jelentőségét korábban már a Közép-Tiszán is hangsúlyozták (TALLÓSI 2013), Észak-Amerikában pedig más növénynemzetségek esetén átfogóan vizsgálták ezt a kérdést (ROSSEL et al. 2014).

Egy Tisza mentén készült jelentésben a fehér füz, törékeny füz (Salix fragilis), rekettyefüz (Salix cinerea), fehér nyár, szürke nyár és nemesnyár mellett a megrágott, kidöntött fajok listáján az amerikai kőris, magyar kőris (Fraxinus angustifolia subsp. pannonica) és kocsányos tölgy (Quercus robur) is szerepelt (MERCSÁK 2006). A Közép-Tisza-Jászság Természetvédelmi Tájegység területén végzett monitoring során a fogyasztott fafajok területenként kerültek feljegyzésre: füzfajok 19, öshonos nyárfajok 9, nemesnyár 3, amerikai kőris 9, gyalogakác 6 helyszínen (TALLÓsI 2013).

Az itt bemutatott vizsgálatban a csatornák mentén számos egyéb fafaj megrágása, kidöntése bizonyítja, hogy a hód jól alkalmazkodik az egyedi táplálékkínálati viszonyokhoz, a táplálékspektruma igen széles. Magyarország más térségeiben, így a Kerka mentén is igazolták ezt a változatosságot, a hód keményfákat, gyümölcsfákat és kökényt is megrág (PRÁVICs 2012). A Mura menti és szigetközi helyi lakosok szintén számos fafaj, köztük díszfák kidöntését is tapasztalták (JUHÁsz et al. 2017). Egy Csehországban készült vizsgálat során azt mutatták ki, hogy a legjelentősebb mértékben hasznosított fafajok a következö nemzetségekbe tartoznak: Salix, Populus, Ulmus, Qercus, Prunus, Fraxinus, Betula, Alnus, Acer (VOREL 2015). A hódok döntően puhafákból álló kínálat esetén is jelentős mennyiségben fogyaszthatnak egyéb fásszárúakat (Alnus spp., Corylus spp., Fraxinus spp., Prunus spp.), ennek lehetséges magyarázata a kiegészítő tápanyagok iránti igény (NOLET et al. 1994). Az eurázsiai hód nem csak fásszárúakkal táplálkozik, a vegetációs időszakban étrendjében egyes lágyszárú növények is jelentős szerepet kapnak (NOLET et al. 1995, KROJEROVÁ-PROKEŠOVÁ et al. 2010).

A Dél-Alföldön a hódok tevékenysége kapcsán saját ismereteim és felkért adatközlőim véleménye szerint eddig nem jelentkezett komoly konfliktus sem gazdálkodói, sem vízügyi oldalról. Nemesnyarak kidöntése a felmért területen összesen három helyszínen fordult elő. Az ország más térségeiben ez a hatás sokkal jelentősebb, valamint a kotorékásásból és a 
gátépítésből esetenként további problémák származhatnak (CZABÁN 2016). A hullámtéren kívül itt is lehetnek olyan alkalmas élőhelyek, ahol a hódrágás a helyiek számára értéket képviselö fákat veszélyeztethet. Ezen fák egyedi védelme legegyszerübben $1 \mathrm{~m}$ magas, erős anyagú dróthálóvál lehetséges (VALACHOVIČ 2014). Folyóink mentén a vízbe borult, nagyobb törzsek hozzátartoznak a terület látképéhez, valamint ökológiai szereppel is bírnak. Olykor azonban a vízügyi érdek a torlaszképzés, vagy a vízügyi mütárgyakon való fennakadás miatt megkívánja az eltávolításukat. Ilyenkor érdemes a helyszínen hagyni a kidőlt fák vékony, vágástéri hulladéknak minősülő ágait (VALACHOVIČ 2014, VARJU \& JÁNOSKA 2015). Ezek ugyanis friss állapotukban táplálékot jelentenek a hód számára, így mérsékelhetik az ép törzseket érintő rágási tevékenységet, tehát a későbbiekben jelentkező hódkárt. Törekedni kell továbbá legalább egy keskeny, változatos szerkezetü, föként őshonos fajokból álló parti sáv, különösen a fiatal füzesek megőrzésére, ebben a tekintetben a természetvédelmi érdek és a hódkár megelőzéséhez füződő érdek találkozhat.

A hódok egyedszámával párhuzamosan a rágott fák mennyisége, az élőhelyátalakítás mértéke, tehát a hatások ökológiai jelentősége is növekszik. Emellett érintetté válhatnak a helyi lakosok, gazdálkodók, hiszen a faj újabb és újabb élettereket kolonizál, lakott területekre is eljut. A dél-alföldi térséget csupán megmintázó vizsgálatom felhívja a figyelmet egy minden folyószakaszra, holtágra és csatornára kiterjedő, pontos állomány-monitoring szükségességére, amit javasolt néhány évente megismételni.

Köszönetnyilvánítás. Szeretnék köszönetet mondani BogdÁNY ZOLTÁN, JANKULÁR ZsOLT, SEBESTYÉN LÁSZLÓ és LUSTYIK GÁBOR halöröknek (KHESZ), AlBERT ANDRÁS, BÁRTOL ISTVÁN, PUSKÁs József (KNPI), LovÁszi Péter, Harsányi Dezsö, ÖZE PÉter (KMNPI), SAllai Zoltán (HNPI) természetvédelmi öröknek, SOMODI IsTVÁN nyugalmazott természetvédelmi örnek (KNPI), GRUBER TAMÁSnak (WWF MagYarorszÁG), BÁlint DÉNES, FÜlÖP TIHAMÉR, Terhes AtTILA természetvédelmi szakembereknek, TószÖGI GYÖRGYnek (KHESZ), DrÖsSZler ISTVÁN, DusEK ANDRÁs és HOLÓKA DEMETER PÉTER helyi lakosoknak a terepi segítségnyújtásért és a kiegészítő adatokért. Továbbá köszönöm az információkat azoknak az adatközlőknek, akik fotókkal bizonyított előfordulási adatokkal gazdagították a térség hódjaival kapcsolatos ismereteket. A publikációval kapcsolatos szakmai segítséget CZABÁN DÁVIDnak, AlBERT ANDRÁSnak, DR. BIRÓ MARIANNÁnak (témavezetőmnek) és DR. MOLNÁr ZsolTnak, a GIS munkához nyújtott segítséget pedig az MTA ÖK Informatikai Laboratóriumának köszönöm. Hálás vagyok a WWF Magyarországnak, amiért a rendelkezésemre bocsátották a korábbi monitoring-jelentéseket. A publikáció a Nemzeti Tehetség Program (NTPNFTÖ-17-B-0494), Emberi Erőforrások Minisztériuma, Emberi Erőforrás Támogatáskezelö támogatásával készült.

\section{Irodalomjegyzék}

Allen, A. W. (1982): Habitat suitability index models: Beaver. US Department of the Interior, Fish and Wildlife Service Biological Report 82(10.30 Revised), Washington, 20 pp.

Bаломі, B. (2011): Az eurázsiai hód (Castor fiber) visszatelepitésének tapasztalatai Magyarországon. WWF Magyarország, Budapest, 54 pp.

BozSÉR, O. (2001): Hódok az óvilágban. WWF Magyarország, Budapest, 28 pp. 
BozSÉR, O. (2002): Hódélöhely alkalmassági felmérés a Közép-Tiszai Tájvédelmi Körzetben. WWF Magyarország, Budapest, 13 pp.

BozSÉR, O. (2003): Szigetközi hódelőfordulások 2003 nyarán. Kézirat, WWF Magyarország, Budapest, $7 \mathrm{pp}$.

CAmpbell, R. D., Rosell, F., Nolet, B. A., \& Dijkstra, V. A. (2005): Territory and group sizes in Eurasian beavers (Castor fiber): echoes of settlement and reproduction? Behavioral Ecology and Sociobiology 58(6): 597-607. https://doi.org/10.1007/s00265-005-0942-6

Campbell-Palmer, R., Schwab, G., Girling, S., Lisle, S. \& Gow, D. (2015): Managing wild Eurasian beavers: a review of European management practices with consideration for Scottish application. Scottish Natural Heritage Commissioned Report No. 812. Scottish Natural Heritage, Inverness, United Kingdom, $51 \mathrm{pp}$.

ČAnÁdy, A., Krišovský, P., Bajomi, B., Huber, A., CzABÁn, D., \& OlekšÁk, M. (2016): Is new spread of the European beaver in Pannonian basin an evidence of the species recovery? European Journal of Ecology 2(2): 44-63. https://doi.org/10.1515/eje-2016-0015

CZABÁN, D. (2003): A Hanságba visszatelepített hódok (Castor fiber) élőhely- és táplálékválasztási szokásai. MSc diplomadolgozat, Eötvös Loránd Tudományegyetem, Budapest, 71 pp.

CZABÁN, D. (2016): Hódok a Szigetközben. In: KoRDA, M. (szerk.): Az erdögazdálkodás hatása az erdők biológiai sokféleségére. Duna-Ipoly Nemzeti Park Igazgatóság, Budapest, pp. 403-418.

CZABÁN, D. (2017): A hód állományának vizsgálata az FHNP működési területén. Kutatási jelentés. Fertő-Hanság Nemzeti Park Igazgatóság, Sarród, 45 pp.

Fustec, J., LodÉ, T., LE JACQUES, D. \& CORMIER, J. P. (2001): Colonization, riparian habitat selection and home range size in a reintroduced population of European beavers in the Loire. Freshwater Biology 46: 1361-1371. https://doi.org/10.1046/j.1365-2427.2001.00756.x

HAARBERG-BOzSÉR, O. (2005): Hódélőhely alkalmassági felmérés az Alsó-Tisza-vidékén. WWF Magyarország, Budapest, $13 \mathrm{pp}$

HAARBerg, O. (2007): Amit a hódról tudni érdemes. Az eurázsiai hód Magyarországon - visszatelepités, védelem és állományszabályozás. WWF füzetek 26. WWF Magyarország, Budapest, 30 pp.

Halley, D., Rosell, F., \& SAveljev, A. (2012): Population and distribution of Eurasian beaver (Castor fiber). Baltic Forestry 18(1): 168-175.

HARTMAN, G. (1996): Habitat selection by European beaver (Castor fiber) colonizing a boreal landscape. Journal of Zoology 240(2): 317-325. https://doi.org/10.1111/j.14697998.1996.tb05288.x

Ionescu, G., Popa, M., Pașca, C., Sīrbu, G., Scurtu, M., Visan, D. \& JuRJ, R. (é.n.): Support for reintroduced beaver population in Romania. Final report. The Rufford Small Grants Foundation Carpathians Foundation, Brasov, Romania, 9 pp.

JoHN, F. \& KostKAN, V. (2009): Compositional analysis and GPS/GIS for study of habitat selection by the European beaver, Castor fiber in the middle reaches of the Morava River. Folia Zoologica 58: 76-86.

JuhÁsz, E., BABAi, D., Biró, M., MolnÁR, Z., \& Ulicsni, V. (2017): Az eurázsiai hód (Castor fiber) táplálkozási és fásszárú-használati szokásaival kapcsolatos helyi tudás két évtizeddel a visszatelepítések kezdete után a Kárpát-medencében. Természetvédelmi Közlemények 23: 182-200.

KrojerovÁ-ProkeŠovÁ, J., BARANČEKovÁ, M., HAMŠíkovÁ, L., \& Vorel, A. (2010). Feeding habits of reintroduced Eurasian beaver: spatial and seasonal variation in the use of food resources. Journal of Zoology 281(3): 183-193. https://doi.org/10.1111/j.1469-7998.2010.00695.x

LELKES, A. (2013). Hód előfordulás Zala megyében 2013. Kézirat, WWF Magyarország, Budapest, 8 pp. 
Macdonald, D. W., Tattersall, F. H., Rushton, S., South, A. B., Rao, S., Maitland, P., \& STRACHAN, R. (2000): Reintroducing the beaver (Castor fiber) to Scotland: a protocol for identifying and assessing suitable release sites. Animal Conservation forum. 3(2): 125-133. https://doi.org/10.1111/j.1469-1795.2000.tb00237.x

MercsáK, J. L. (2006): Taktaközi hódmonitoring 2005/2006. Kézirat, WWF Magyarország, Budapest, 2 pp.

Nolet, B. A., Hoekstra, A. \& OtTenheim, M. M. (1994): Selective foraging on woody species by the beaver Castor fiber, and its impact on a riparian willow forest. Biological Conservation 70: 117-128. https://doi.org/10.1016/0006-3207(94)90279-8

Nolet, B.A., VAN DER Veer, P.J., Evers, E.G.J. \& OtTEnheim, M.M. (1995): A linear programming model of diet choice of free-living beavers. Netherlands Journal of Zoology 45: 317-335.

Nolet, B. A., \& Rosell, F. (1998): Comeback of the beaver Castor fiber: an overview of old and new conservation problems. Biological Conservation 83: 165-173. https://doi.org/10.1016/ S0006-3207(97)00066-9

PRÁviCs, M. (2012): Az eurázsiai hód (Castor fiber) állományának és táplálkozásának vizsgálata a Kerka mentén. Szakdolgozat, Nyugat-Magyarországi Egyetem, 72 pp.

Rosell, F., Bergan, F., \& PARKER, H. (1998): Scent-marking in the Eurasian beaver (Castor fiber) as a means of territory defense. Journal of Chemical Ecology 24(2), 207-219. https://doi.org /10.1023/A:1022524223435

Rossell Jr, C. R., Arico, S., Clarke, H. D., Horton, J. L., Ward, J. R., \& Patch, S. C. (2014): Forage selection of native and nonnative woody plants by beaver in a rare-shrub community in the Appalachian Mountains of North Carolina. Southeastern naturalist 13(4): 649-662. https://doi.org/10.1656/058.013.0415

STOCKeR, G. (1985): Biber (Castor fiber L.) in der Schweiz. Probleme der Wiedereinbürgerung aus biologischer und ökologischer Sicht. Bericht Nr. 247. Eidgenössische Anstalt für forstliches Versuchswesen, Birmensdorf., 149 pp.

TALLÓsI, B. (2007): Hód-megfigyelések a Közép-Tisza-Jászság Természetvédelmi Tájegység területén 2006. február 10. és 2007. április 27. között. Kézirat, WWF Magyarország, Budapest, 26 pp.

TALLÓsI, B. (2013): A betelepített hódpopulációra vonatokozó megfigyelési adatok és a faj természetvédelmi helyzete a Hortobágyi Nemzeti Park Igazgatóság Közép-Tisza-Jászság Természetvédelmi Tájegységének területén 2012 decembere és 2013 márciusa között. Kézirat, WWF Magyarország, Budapest, $28 \mathrm{pp}$.

VALACHOviČ, D. (2014): Manual of beaver management within Danube River basin. Danube Parks, $76 \mathrm{pp}$.

VARJU, J. \& JÁNOSKA, F. (2015): Az eurázsiai hód (Castor fiber Linnaeus, 1758) fás szárú táplálékpreferenciája és élöhelyhasználata a Mosoni-Dunán. Erdészettudományi Közlemények 5: 129 144. https://doi.org/10.17164/EK.2015.009

Vorel, A., VÁlková, L., Hamšíková, L., Maloñ, J., \& Korbelová, J. (2015). Beaver foraging behaviour: Seasonal foraging specialization by a choosy generalist herbivore. Behavioral ecology and sociobiology 69(7): 1221-1235. https://doi.org/10.1007/s00265-015-1936-7

Vorel, A., Dostál, T., Uhlíková, J., Korbelová, J., \& Koudelka, P. (2016): Handbook for Coexisting with beavers. Czech University of Life Sciences, Prague, 136 pp. 


\title{
Distribution and activity of the Eurasian beaver (Castor fiber LINNAEUS, 1758) on the southern part of the Great Hungarian Plain, Hungary
}

\section{ERIKA JUHÁSZ}

Eötvös Loránd University, Department of Plant Systematics, Ecology and Theoretical Biology, Pázmány Péter sétány 1/C, H-1117 Budapest, Hungary

E-mail: juhasz.erika43@gmail.com

\section{ÁLLATTANI KÖZLEMÉNYEK (2018) 103(1-2): 15-32.}

\begin{abstract}
In the last few decades, the Eurasian beaver has been successfully and quickly colonizing suitable habitats throughout Europe, thus in Hungary as well. Despite its importance, monitoring the species' distribution and population size received little attention on the southern part of the Great Hungarian Plain. This paper presents a field survey focusing principally on the Körös (Criș) and Maros (Mureș) Rivers (2016-2018), and additional data collected from local people. 20 beaver colonies were found on a $39.4 \mathrm{~km}$ long section of Maros River, and 40 colonies on a $99.7 \mathrm{~km}$ long stretch of Körös River. In this region beavers are spreading intensively in the floodplains while their presence on backwaters and small channels outside is not so typical. Data were collected about the woody food supply and its utilisation by the beaver, too.
\end{abstract}

Key words: monitoring, distribution, territory, Körös, Maros, Lower Tisza. 